\title{
ACTIVITIES OF LOCAL GOVERNMENT AT STIMULATING INNOVATIVENESS IN THE LEARNING REGION - STUDY OF LESSER POLAND VOIVODESHIP
}

\author{
ZOFIA GRÓDEK-SZOSTAK, ${ }^{1}$ DANUTA KAJRUNAJTYS, ${ }^{2}$ GABRIELA MALIK, ${ }^{3}$ \\ ANNA SZELĄG-SIKORA ${ }^{4}$ \\ ${ }^{1}$ Cracow University of Economics, Department of Economics an Organization of Enterprises, POLAND \\ e-mail: grodekz@uek.krakow.pl \\ ${ }^{2}$ Cracow University of Economics, Department of International Management, POLAND \\ e-mail: dkajrunajtys@wsei.edu.pl \\ ${ }^{3}$ Higher School of Economics and Computer Science in Cracow, POLAND \\ e-mail: gmalik@wsei.edu.pl \\ ${ }^{4}$ University of Agriculture in Cracow, Faculty of Production and Power Engineering, POLAND \\ e-mail: anna.szelag-sikora@ur.krakow.pl
}

RECEIVED
ACCEPTED
JEL
CLASSIFICATION

KEYWORDS learning region, innovation, Polan Lesser Poland Voivodeship

ABSTRACT The main subject considered in this article is the idea of a "learning" region and if the Małopolskie Voivoidship has the features, which allow to consider it as a such. The analysis of the statistical data for the years 2007-2016 has led to the conclusion that such a term is legitimate with regard to the Małopolskie Voivodship. It is necessary, however, to take into consideration that it is the capital city of the region, Kraków, that is the main contributor, as the infrastructure supporting knowledge and innovativeness is concentrated mainly within the borders of the Kraków Metropolitan Area.

\section{Introduction}

As paradoxical as it may seem, the globalization processes are becoming the means of growth on the regional scale, providing resources for stimulating, creating and developing local innovative processes. The experiences of participants of these processes result in an increasingly popular perception of the innovative processes as complex (systemic) phenomena, which confirms some degree of readiness to co-operate on the regional scale. 
These activities include e.g.: the involvement of regional or local authorities, which create a favourable atmosphere and provide basic infrastructure, the activity of local research units, as well as the presence of centres for supporting entrepreneurship (business support institutions) and companies which operate independently, or as a network. One proposition says that „with a combination of factors enabling advantageous participation in a global economy, regions are a natural area for economic activities in a globalized world" (Godowska, 2012, pp. 278-286.).

The main aim of this study is to identify the situation of the Malopolskie Voivodship in the scope of the years 2007-2016 as an area where the local government carries out effective actions in order to stimulate innovativeness. The first part of the article explains the concept of a "learning" region and innovativeness in terms of regions. Next, the study discusses the essence of regional innovation and presents the basic statistical characteristics of the Malopolskie Voivodship, followed by its analysis and conclusions. The paper was financed from the funds allocated to the Faculty of Management at the Cracow University of Economics, as part of a grant to support research capacity.

\section{The concept of the learning region - a literature review}

Richard Florida's concept of "learning" regions is based on an assumption that the ability to create specific and strategic resources is crucial for the competitiveness of an area (Jewtuchowicz, 2005, p. 123). The issue of the learning region is the subject of discussion for researchers who have already tried to define it (Table 1). In most of the studies, the authors refer to the article by Florida, considered a precursor of the term. According to him, a learning region should be understood as storage of knowledge and ideas that provides the appropriate environment and infrastructure to facilitate the flow of knowledge, ideas and learning (Florida, 1995).

Table 1. The review of the „learning region” definitions

\begin{tabular}{ll}
\hline \multicolumn{1}{c}{ Author } & \multicolumn{1}{c}{ Definition characteristics for „learning region” } \\
\hline OECD & $\begin{array}{l}\text { A region with a dense network of companies co-operating with the higher education and research sector institutions; } \\
\text { politics are based mainly on the creating structures for regional clusters, for a connection between business and } \\
\text { science, as well as on promoting social implication and working through the lifelong learning process }\end{array}$ \\
\hline Olivier Torrès & $\begin{array}{l}\text { Competitiveness factors, which influence on global competitiveness (innovativeness, flexibility, network strategies, } \\
\text { acquisition of knowledge, entrepreneurship) will be settled in a local development conditions }\end{array}$ \\
\hline Leo Baumfeld & Three dimensions of learning region: \\
& - measured activities for supporting citizens education, \\
& - measured activities in order to enhance and make a network for educational skills of the region (schools, universities, \\
& vocational education) for brightening educational insfrastructure and broadening regional base of knowledge, \\
& - constant investments in order to integrate education subsystems in the region for building permanent process of the \\
& common learning and innovations \\
\hline Andrzej Klasik, Florian Kuźnik & $\begin{array}{l}\text { It is the knowledge, experience and competences area, considered in four perspectives: cohesion's, capital, adaptive } \\
\text { and future }\end{array}$ \\
\hline Roel Rutten, Frans Boekema & $\begin{array}{l}\text { Regional players are concerned in a cooperation and coordination for common benefits, which lead to regional } \\
\text { learning process. Region features influence the degree to which regional learning process contributes to regional } \\
\text { renovation }\end{array}$ \\
\hline
\end{tabular}

Source: OECD (2002), p. 38; Torrès (2004), pp. 23-41; Baumfeld (2005), pp. 39-51; Klasik, Kuźnik (2007), pp. 9-28; Rutten, Boekema (2007), pp. 127-142; Czyżewska (2012), pp. 32-50.

Learning is the most important process taking place within a learning region. It allows organizations to develop structures and systems more adjusted to the changes in a turbulent environment (Marszałek, 2011, pp. 51-70; 
Domański 2001, pp. 69-70; Kajrunajtys, 2016, pp. 124-140). As part of work in the field of learning at the regional level, the necessity to learn as an element conditioning the creation of innovation is emphasized (Pietrzyk, 2000, pp. 28-30).

It should be noted that the question of a region's "learning" is treated as a metaphorical term, for it is individuals or organizations, as a part of regions, that participate in the learning processes, and not the regions considered as an entirety (Wink, 2010, pp. 499-511; Jocoy, 2004, pp. 19-21; Normann, 2005, pp. 520-542; Lambooy, 2000, pp. 17-37; Oinas, 2000, pp. 57-69).

\section{Innovativeness on the regional basis}

A literature query has proven a variety of definitions of innovation. Many of them regard to the definition and typology of innovation proposed by the third edition of the Oslo Manual (OECD, 2006) or its earlier versions. Innovation is understood as "an implementation of a new or significantly improved product (goods or services), or process, a new marketing or organizational method within an economic practice, organization of a workplace or relationships with the environment" (OECD, 2006, pp. 48, 50-54).

Nowadays, regions are also subject to the factors and mechanisms characteristic to economy: acceleration of the innovative process, and a simultaneous cumulative utilization of innovations in creating consecutive innovations (Gorzelak, Smetkowski, 2005, p. 25; Korenik, 2011, p. 79; Markowska, 2010, pp. 13-23).

Researchers understand innovativeness on the regional basis as:

a) the ability of entities in the region to continuously search for and use in economic practice the results of $R \& D$, the development of production technologies and services used, the introduction of new methods and techniques in management, as well as the improvement and development of infrastructure and knowledge resources (Niedzielski, 2008, pp. 150-152);

b) a system of internal conditions and features of a region, enabling its innovative processes to take place (Nowakowska, 2009, pp. 19-41);

c) in subject terms - innovative abilities of individual actors of the regional innovation scene and synergy mechanisms occurring in this system; in process terms - the sum of the component processes that create the innovation process such as the process of learning, adaptation, diffusion or cooperation; the innovation processes are fostered by pro-innovation attitudes: creativity, openness, flexibility or entrepreneurship (Nowakowska, 2009, pp. 19-41).

\section{Malopolskie Voivodship - a region of innovations}

Gardiner and Martin (2004, p. 58) describe basic factors for competitiveness, which are crucial for the regions according to the level of their development. And so the characteristics of a learning region, where competitiveness is based on innovation, is based on the size of selected indicators such as the level of GDP per capita PPS, the degree of urbanization, employment level in the service sector and in HRST, sectoral diversity and the quality of life, which should be high. A very broad review of the regional indicators of competitiveness can be found in e.g. the works of Snieška and Bruneckiene (2009, pp. 45-57); Brooksbank and Pickernell (1999, pp. 310-326); Pinelli et al. (1998, pp. 1-15).

Table 2 presents chosen indicators characterizing Malopolskie Voivodship to verify how this region comes out against the other regions in Poland and whether the term "learning region" is legitimate in reference to it. Additionally, 
the values of the chosen indicators for Poland as a whole and $28 \mathrm{EU}$ countries were added for comparison. The time range for the analysis is subject to availability of statistical data and includes the years 2007-2012 (in case of data for the GDP, until 2015; in case of data for the HRST, until 2016, in case of data for R\&D, until 2014). The position of the Malopolskie Voivodship in the ranking, including all 16 voivodships of Poland, is presented in round brackets.

Table 2. Chosen indicators of competitiveness for Malopolskie Voivodship as a learning region in the years 2007-2016 (against other Polish voivodships and EU member countries)

\begin{tabular}{|c|c|c|c|c|c|c|c|c|c|c|c|}
\hline Indicators & Region & 2007 & 2008 & 2009 & 2010 & 2011 & 2012 & 2013 & 2014 & 2015 & 2016 \\
\hline 1 & 2 & 3 & 4 & 5 & 6 & 7 & 8 & 9 & 10 & 11 & 12 \\
\hline \multirow{4}{*}{$\begin{array}{l}\text { GPD per capita } \\
\text { of PPS (euro) }\end{array}$} & Małopolska & & & & & & & & & & \\
\hline & Region & $12,300(8)$ & $13,000(6)$ & $13,000(6)$ & $13,900(7)$ & $15,100(7)$ & $15,700(7)$ & $15,900(7)$ & $16,600(7)$ & $17,800(7)$ & - \\
\hline & Poland & 13,800 & 14,500 & 14,600 & 15,900 & 17,000 & 17,800 & 17,900 & 18,600 & 19,800 & - \\
\hline & UE-28 & 26,000 & 26,100 & 24,500 & 25,500 & 26,100 & 26,600 & 26,700 & 27,600 & 28,900 & - \\
\hline \multirow{3}{*}{$\begin{array}{l}\text { GDP per capita in } \\
\text { PPS (as } \% \text { of the } \\
\text { EU-28 average) }\end{array}$} & Małopolska & & & & & & & & & & \\
\hline & Region & $47(7)$ & $50(7)$ & $53(7)$ & $55(7)$ & $58(6)$ & $59(6)$ & $59(6)$ & $60(6)$ & $62(6)$ & - \\
\hline & Poland & 53 & 55 & 60 & 62 & 65 & 67 & 67 & 68 & 69 & - \\
\hline \multirow{4}{*}{$\begin{array}{l}\text { Total R+D expenses } \\
\text { per capita (GERD*) } \\
\text { (euro) }\end{array}$} & Małopols & & & & & & & & & & \\
\hline & Region & $64.6(2)$ & $77.7(2)$ & $64.9(2)$ & $83.3(2)$ & $89.2(2)$ & $118.5(2)$ & $119.5(2)$ & $133.3(2)$ & - & - \\
\hline & Poland & 46.3 & 57.6 & 55.0 & 68.6 & 74.5 & 90.1 & 90.3 & 101.6 & - & - \\
\hline & UE-28 & 460.7 & 479.6 & 472.9 & 490.9 & 516.7 & 536.3 & 543.4 & 564.4 & - & - \\
\hline \multirow{4}{*}{$\begin{array}{l}\text { Total expenses } \\
\text { for } R+D \text { as the } \\
\text { percentage of GDP }\end{array}$} & Małopols & & & & & & & & & & \\
\hline & Region & $0.88(2)$ & $0.91(2)$ & $0.88(2)$ & $1.00(2)$ & $1.00(2)$ & $1.31(2)$ & $1.30(2)$ & $1.38(2)$ & - & - \\
\hline & Poland & 0.56 & 0.60 & 0.66 & 0.72 & 0.75 & 0.88 & 0.87 & 0.94 & - & - \\
\hline & UE-28 & 1.77 & 1.84 & 1.93 & 1.93 & 1.97 & 2.01 & 2.03 & 2.04 & - & - \\
\hline \multirow{4}{*}{$\begin{array}{l}\text { Total number of the } \\
\text { employed at HRST } \\
\text { (th.) }\end{array}$} & Małopolska & & & & & & & & & & \\
\hline & Region & $485.0(4)$ & $505.8(3)$ & $524.5(3)$ & $533.6(3)$ & $568.8(3)$ & $616.4(3)$ & $639.3(3)$ & $647.7(3)$ & $635.4(3)$ & $724.4(3)$ \\
\hline & Poland & $5,971.5$ & $6,211.9$ & $6,584.7$ & $6,770.0$ & $6,961.3$ & $7,241.5$ & $7,506.4$ & $7,830.6$ & $8,039.5$ & $8,170.2$ \\
\hline & UE-28 & 100,019 & 103,472 & 105,784 & 107,466 & 111,362 & 114,850 & 117,401 & 120,352 & 123,025 & 125,877 \\
\hline \multirow{4}{*}{$\begin{array}{l}\text { Number } \\
\text { of the employed } \\
\text { at the HRST } \\
\text { as a proportion } \\
\text { of the professionally } \\
\text { active population }\end{array}$} & Małopolska & & & & & & & & & & \\
\hline & Region & $30.3(6)$ & $31.3(6)$ & $32.4(6)$ & $32.8(6)$ & $34.1(5)$ & $36.0(5)$ & $36.8(5)$ & $37.9(5)$ & $40.1(5)$ & $42.0(5)$ \\
\hline & Poland & 30.8 & 31.9 & 33.3 & 34.3 & 34.9 & 36.0 & 37.3 & 38.8 & 40.1 & 41.1 \\
\hline & UE-28 & 36.8 & 37.4 & 38.0 & 38.7 & 40.1 & 40.9 & 41.7 & 42.5 & 43.3 & 44.1 \\
\hline \multirow{4}{*}{$\begin{array}{l}\text { Total number of the } \\
\text { employed at the } \\
\text { HRST core (th.) }\end{array}$} & Małopolska & & & & & & & & & & \\
\hline & Region & $203.1(3)$ & $222.3(3)$ & $236.5(3)$ & $228.6(3)$ & $254.7(3)$ & $281.0(3)$ & $285.4(3)$ & $291.3(3)$ & $299.3(3)$ & $340.3(3)$ \\
\hline & Poland & $2,428.7$ & $2,567.6$ & $2,814.7$ & $2,887.2$ & $2,961.7$ & $3,126.7$ & $3,247.8$ & $3,463.9$ & $3,617.3$ & $3,640.5$ \\
\hline & UE-28 & $37,536.5$ & $39,089.5$ & $40,269.0$ & $41,007.9$ & $44,213.3$ & $45,319.5$ & $46,517.4$ & $47,487.6$ & $48,988.0$ & $50,584.6$ \\
\hline \multirow{4}{*}{$\begin{array}{l}\text { Number of the } \\
\text { employed at the } \\
\text { HRST core as } \\
\text { a proportion } \\
\text { of the professionally } \\
\text { active population }\end{array}$} & Małopolska & & & & & & & & & & \\
\hline & Region & $14.6(7)$ & $15.8(4)$ & $16.8(4)$ & $16.6(5)$ & $18.0(3)$ & $19.5(3)$ & $19.4(4)$ & $20.1(4)$ & $21.9(4)$ & $23.0(2)$ \\
\hline & Poland & 14.4 & 15.1 & 16.3 & 16.9 & 17.2 & 18.1 & 18.7 & 19.9 & 20.8 & 21.1 \\
\hline & UE-28 & 15.8 & 16.3 & 16.7 & 17.1 & 18.5 & 18.8 & 19.2 & 19.6 & 20.1 & 20.7 \\
\hline \multirow{3}{*}{$\begin{array}{l}\text { Number } \\
\text { of researchers } \\
\text { and engineers } \\
\text { employed at the } \\
\text { HRST (th.) }\end{array}$} & $\begin{array}{l}\text { Małopolska } \\
\text { Region }\end{array}$ & $73.8(3)$ & $78.4(3)$ & 79.7 (3) & $73.0(4)$ & $88.8(3)$ & $105.2(3)$ & $100.7(3)$ & $101.3(3)$ & $100.6(3)$ & $111.4(3)$ \\
\hline & Poland & 829.8 & 848.1 & 902.7 & 910.0 & 991.9 & $1,059.4$ & $1,084.1$ & $1,130.7$ & $1,140.9$ & $1,145.7$ \\
\hline & UE-28 & 11,238 & 11,624 & 11,784 & 11,956 & 15,376 & 15,534 & 15,865 & 16,124 & 16,568 & 17,182 \\
\hline
\end{tabular}




\begin{tabular}{|c|c|c|c|c|c|c|c|c|c|c|c|}
\hline 1 & 2 & 3 & 4 & 5 & 6 & 7 & 8 & 9 & 10 & 11 & 12 \\
\hline \multirow{4}{*}{$\begin{array}{l}\text { Number } \\
\text { of researchers } \\
\text { and engineers } \\
\text { employed at } \\
\text { the HRST as } \\
\text { a proportion } \\
\text { of the professionally } \\
\text { active population }\end{array}$} & Małopolska & & & & & & & & & & \\
\hline & Region & $5.3(4)$ & $5.6(3)$ & $5.7(3)$ & $5.3(5)$ & $6.3(4)$ & $7.3(3)$ & $6.8(5)$ & $7.0(4)$ & $7.4(2)$ & $7.5(3)$ \\
\hline & Poland & 4.9 & 5.0 & 5.2 & 5.3 & 5.8 & 6.1 & 6.3 & 6.5 & 6.6 & 6.7 \\
\hline & UE-28 & 4.7 & 4.8 & 4.9 & 5.0 & 6.4 & 6.4 & 6.6 & 6.6 & 6.8 & 7.0 \\
\hline \multirow{4}{*}{$\begin{array}{l}\text { Total number } \\
\text { of patented } \\
\text { registrations per } \\
\text { million inhabitants }\end{array}$} & $\begin{array}{l}\text { City } \\
\text { of Kraków }\end{array}$ & 16.714 & 19.363 & 38.549 & 29.198 & 53.374 & 50.059 & - & - & - & - \\
\hline & Małopolska & & & & & & & & & & \\
\hline & Region & 7.957 (2) & $9.866(2)$ & $14.697(2)$ & $15.061(3)$ & 23.728 (1) & $18.498(3)$ & - & - & - & - \\
\hline & Poland & 5.299 & 6.121 & 7.559 & 9.477 & 10.081 & 11.222 & - & - & - & - \\
\hline \multirow{3}{*}{$\begin{array}{l}\text { Number of high- } \\
\text { tech type patent } \\
\text { registrations per } \\
\text { million inhabitants }\end{array}$} & $\begin{array}{l}\text { City } \\
\text { of Kraków } \\
\text { Małopolska }\end{array}$ & 1.428 & 3.741 & 3.313 & 3.68 & 2.31 & 7.332 & - & - & - & - \\
\hline & Region & $0.33(10)$ & $1.372(5)$ & $1.065(7)$ & $0.939(6)$ & $0.638(9)$ & $1.665(5)$ & - & - & - & - \\
\hline & Poland & 1.014 & 0.857 & 1.098 & 1.693 & 1.574 & 1.489 & - & - & - & - \\
\hline
\end{tabular}

Source. own study based on Eurostat.

As it was shown in Table 2, the Malopolskie Voivodship is becoming more and more competitive, even though comparative statistics demonstrate that it is below the national average and it is quite far from EU standards. Its GDP per capita in the considered period increased notably.

The indicators that make it possible to better illustrate the knowledge production process in the region's economy than by means of GDP are, above all, those regarding R\&D and employment in the technology and knowledge-based sectors. It is expenditure on research and development (GERD) that is one of the most commonly used measures, which approximates innovative attitudes and involvement in the creation of knowledge of regions and countries. Observing the results presented in Table 2, it can be noticed that the Malopolskie Voivodship ranks second on the national scale, giving way only to the Mazowieckie Voivodship.

Human resources are one of the pillars of the development of a knowledge-based economy. It is responsible for its formation and circulation. For statistical purposes, the most often used index is the HRST, describing human resources in science and technology, i.e. graduates and/or employed in scientific and technological professions, which determine the number of employees actively participating in research and creation of technological innovations. As demonstrated by the results in Table 2, the number of employees in this sector in the Małopolskie Voivodship in 2007 exceeded $30 \%$ of the professionally active population and is showing a growing trend. In 2016 , it reached $42 \%$, ranking 5th in the country and exceeding the national average. The heart of the HRST group is the 'HRST core'. The HRST core is persons meeting both of the above mentioned criteria: having a higher education degree and employed in scientific and technological positions considered to be accelerator of the development of technological innovations. As it can be concluded from the data in Table 2, the number of such persons in Malopolskie Voivodship in 2007 comprised $14.6 \%$ of the professionally active population. This earned the considered region the 7 th position in the ranking. In subsequent years, this percentage gradually increased, giving Małopolska the 2nd place in the region in 2016 (just behind Mazowieckie Voivodship) and was as high as $23 \%$, thus surpassing both the national and EU average. In the analyzed period, Malopolskie Voivodship can also pride in a clearly growing number of employed scientists and engineers. In 2016, the percentage of their employment among the professionally active population 
was at 7.5\%, placing the region on the 3rd position (after Mazowieckie and Dolnośląskie Voivodships) and thus ahead of the national and the EU average.

Another important indicator for assessing the level of development of a knowledge-based economy in a given region is the number of patent applications filed with the European Patent Office (EPO) per one million inhabitants. In general, it can be said that this is an indicator of generation capacity, but also the absorption of knowledge by regional economies represented by companies operating there. Patent statistics are used to assess the innovative activity of a country or region, and thus its competitiveness. The patents themselves are a way of protecting the results of $R \& D$ works and at the same time a reliable resource of information about the already implemented ideas. As shown in the data in Table 2, the number of both general and high-tech type patent applications in Malopolskie Voivodship, calculated per million inhabitants was gradually increasing since 2007, then decreased in 2011, and increased again in 2012. According to data, compared to 2007, there was an increase in the number of patent applications in total by almost $133 \%$ in 2012 , while in the case of high-tech patents, by as much as $405 \%$.

\section{Conclusions}

In the light of the concept of a learning region, the analysis of the situation of the Malopolskie Voivodship based on data in Table 2 allows a conclusion that the term is legitimate with regard to the studied region. At the same time, it is necessary to take into consideration that it is the capital city of the region, Kraków, that is the main contributor, as the infrastructure supporting knowledge and innovativeness is concentrated mainly within the borders of the Kraków Metropolitan Area.

Maintaining this trend is supported by the activities of local government administration for stimulating innovation in the Małopolska region, undertaken since 2013. On the one hand, these activities were dedicated to the academic environment, which is largely focused in the capital of the region. It should be emphasized, though, that the beneficiaries of the activities are enterprises from the entire Małopolskie Voivodship. It is presumed that Malopolskie Voivodship will retain its learning region status in the future.

\section{References}

Baumfeld, L. (2005). Balanced Scorecard für Regionen. Wien: LEADER+ Österreich.

Brooksbank, D.J., Pickernell, D.G. (1999). Regional Competitiveness Indicators. A Reassessment of Methods. Local Economy, 13 (4), $310-326$.

CEAPP (2015). Przyspieszyć niezbędne. Doświadczenia z projektu SPIN - wsparcie transferu wiedzy z uczelni do przedsiębiorstw. Kraków: Uniwersytet Jagielloński, Kraków.

Czyżewska, D. (2012). Budowanie pozycji konkurencyjnej regionu w świetle koncepcji regionu uczącego się. In: E. Łaźniewska, E. Gorynia (eds.), Konkurencyjność regionalna. Koncepcje - strategie - przykłady. Warszawa: Wydawnictwo Naukowe PWN.

Domański, R. (2001). The innovative city. Poznań: Wydawnictwo Akademii Ekonomicznej w Poznaniu.

Florida, R. (1995). Toward the Learning Region. Futures, 27 (5), pp. 528-533.

Gardiner, B., Martin, R. (2004). The factors of Regional Competitiveness. Final Report for the European Comission. Cambridge: University of Cambridge.

Godowska, M. (2012). Region uczący się - uwarunkowania i determinanty rozwoju na przykładzie województwa małopolskiego. Przedsiębiorczość - Edukacja, 8, 278-286.

Gorzelak, G., Smetkowski, M. (2005). Metropolia i jej region w gospodarce informacyjnej. Warszawa: Scholar.

Hudson, R. (1999). The Learning Economy, the Learning Firm and the Learning Region: a Sympathetic Critique of the Limits to Learning. European Urban and Regional Studies, 6 (1), 59-72. 
Jocoy, C.L. (2004). Learning from the inside out: the Social and Spatial Context of Learning within Firms, thesis in geography. The Pennsylvania State University.

Jewtuchowicz, A. (2005). Terytorium i współczesne dylematy jego rozwoju. Łódź: Wydawnictwo Uniwersytetu Łódzkiego.

Kajrunajtys, D. (2016). Obieg informacji na potrzeby konkurowania organizacji w turbulentnym otoczeniu. Zeszyty Naukowe Wyższej Szkoły Ekonomii i Informatyki w Krakowie, 12, 124-140.

Klasik, A., Kuźnik, F. (2007). Regiony uczące się w teorii i polityce rozwoju regionalnego. In: A. Jewtuchowicz (ed.), Wiedza, innowacyjność, przedsiębiorczość a rozwój regionów. Łódź: Wydawnictwo Uniwersytetu Łódzkiego.

Korenik, S. (2011). Region ekonomiczny w nowych realiach społeczno-gospodarczych. Warszawa: CeDeWu.

Lambooy, J. (2000). Learning and Agglomeration Economies: Adapting to Differentiating Economic Structures. In: F. Boekema, K. Morgan, S. Bakkers, R. Rutten (eds.), Knowledge, Innovation and Economic Growth. The Theory and Practice of Learning Regions (pp. 17-37). Cheltenham: Edward Elgar.

Markowska, M. (2010). Innowacyjność w wybranych teoriach rozwoju regionalnego. In: D. Strahl (ed.), Innowacyjność europejskiej przestrzeni regionalnej a dynamika rozwoju gospodarczego (pp. 13-23). Wrocław: Wydawnictwo Uniwersytetu Ekonomicznego we Wrocławiu.

Marszałek, A. (2011). Potencjał naukowo-badawczy uczelni i jego rola w regionie uczącym się (na przykładzie Małopolski). In: T. Domański (ed.), Marketing akademicki. Rola uniwersytetów w promocji miast i regionów (pp. 51-70). Łódź: Wydawnictwo Uniwersytetu Łódzkiego.

Niedzielski, P. (2008). Innowacyjność. In: K. Matusiak (ed.), Innowacje i transfer technologii, Słownik pojęć (pp. 150-152). Warszawa: PARP.

Normann, R. (2005). Can Regions Learn? Critical Assessment of Regions as Arenas for Regional Development. Al \& Society, 19 (4), 520-542.

Nowakowska, A. (2009). Regionalny kontekst procesów innowacji. In: A. Nowakowska (ed.), Budowanie zdolności innowacyjnych regionów (pp. 19-41). Łódź: Wydawnictwo Biblioteka.

OECD (2002). OECD Territorial Reviews. Switzerland, OECD Publishing, Paris.

OECD (2006). OECD Territorial Reviews. France, OECD Publishing, Paris.

Oinas, P. (2000). Distance and Learning: Does Proximity Matter? In: F. Boekema, K. Morgan, S. Bakkers, R. Rutten, Knowledge, Innovation and Economic Growth. The Theory and Practice of Learning Regions (pp. 57-69). Cheltenham: Edward Elgar.

Owen, D.H., Wahl, Z. (2011). Defining Four Pillars for Successful Applied. In: J.R. Howlett (ed.), Innovation through Knowledge Transfer 2010. Berlin Heidelberg: Springer.

Pietrzyk, I. (2000). Polityka regionalna Unii Europejskiej i regiony w państwach członkowskich. Warszawa: Wydawnictwo Naukowe PWN.

Pinelli, D., Giacometti, R., Lewney, R., Fingleton, B. (1998). European Regional Competitiveness Indicators. Discussion Paper 103. Cambridge: Department of Land Economy, University of Cambridge.

Rutten. R., Boekema, F. (2007). The Learning Region: a Conceptual Anatomy. In: R. Rutten, F. Boekema (eds.), The Learning Region. Foundations, State of the Art, Future. Cheltenham: Edward Elgar.

Strzałka, K. (2015). Geneza powstania, sposób funkcjonowania i znaczenie dla koncepcji uniwersytetu badawczego. Zagadnienia Naukoznawstwa, 3 (205), 377-385.

Snieška, V., Bruneckiene, J. (2009). Measurement of Lithuanian Regions by Regional Competitiveness Index. Engineering Economics, 1 (61), 45-57.

Torrès, O. (2004). Lokalna globalizacja czy globalna lokalizacja. Rozważania na temat glokalizacji. In: A. Jewtuchowicz (ed.), Wiedza, innowacyjność, przedsiębiorczość a rozwój regionów (pp. 23-41). Łódź: Wydawnictwo Uniwersytetu Łódzkiego.

Wink, R. (2010). Transregional Institutional Learning in Europe: Prerequisites, Actors and Limitations. Regional Studies, 44 (4), pp. 499-511.

Cite this article aS: Gródek-Szostak, Z., Kajrunajtys, D., Malik, G., Szelagg-Sikora, A. (2018). Activities of local government at stimulating innovativeness in the learning region - study of Lesser Poland voivodeship. European Journal of Service Management, 3 (27/2), 175-181. DOI: 10.18276/ejsm.2018.27/2-21. 